\title{
Some effects of a rotational grazing treatment on cattle preference for plant communities
}

\author{
JOHN W. WALKER, RODNEY K. HEITSCHMIDT, AND STEVE L. DOWHOWER
}

\section{Abstract}

Rotational graxing is commonly assumed to improve livestock distribution compared to continuous graxing, but little evidence supports this contention. Research was conducted on the effects of rotational grazing (RG) compared to continuous grazing (CG) on the preference of cattle for plant communities. Different livestock densities in the RG treatments were created by varying the size of paddocks in a 465-ha, 16-paddock, cell deaigned RG treatment stocked at a rate of $3.6 \mathrm{ha} / \mathrm{cow} / \mathrm{yr}$. Paddock sizes of 30 and 10 -ha were used to simulate RG with 14 (RG-14) and 42-paddocks (RG42), respectively. The CG treatment consisted of a 248-ha pasture stocked at $5.9 \mathrm{ha} / \mathrm{cow} / \mathrm{yr}$. Data consisted of hourly daylight observations of cattle location and activity during 8 seasonal trials lasting 6-15 days. These data were expressed as a percent of the time cattle were observed in each of 4 plant communities and the area surrounding permanent water. Relative electivity (RE), a preference index, and a selectivity index (SI) that measures departures from random distribution were calculated from these data. Relative electivity (i.e., preference) for plant communities was not affected by grazing treatment. However, cattle were less selective for plant communities as livestock density decreased from the RG-42 to the CG treatment. In the RG-14 treatment, the cattle were either unaffected or less selective on the last day than on the first day in a paddock. We hypothesize that grazing systems influence cattle preference for plant communities by affecting the availability of forage biomass per unit land area rather than by their effect on grazing pressure.

Key Words: cattle, grazing behavior, community preference, cell grazing, continuous grazing

The effects of livestock grazing on rangelands are related primarily to the direct effects that defoliation has on the growth and reproduction of individual plants, and the disparity that exists among individual plants in frequency and severity of defoliation as a result of selection. Diet selection involves a hierarchy of decisions by the grazing animal relative to the spatial assemblage of plants across a landscape, that can be classified as: (1) plant community, (2) patch, (3) feeding station, and (4) plant (Senft et al. 1987).

Previous research on spatial distribution patterns of grazing have shown large differences in grazing intensity among plant communities and among patches within communities (Weaver and Tomanek 1951, Wagnon 1968, Low et al. 1981, Roath and Krueger 1982, Tanner et al. 1984, Ring et al. 1985). Investigations designed to determine the capacity of grazing systems to ameliorate community or patch selective grazing have demonstrated variable results. Smith and Owensby (1978) and Ring et al. (1985) reported that intensive early grazing (IES) compared to season long contin-

\footnotetext{
At the time of this research authors were Tom Slick Fellow, Range Science Department, Texas A\&M University, College Station 77843; professor, and research associate, Texas Agr. Exp. Sta., Box 1658, Vernon 76384. Walker presently is animal scientist, USDA/ARS Sheep Experiment Station, HC 62 Box 2010, Dubois, Ida. 83423.

Appreciation is expressed to the Swen R. Swenson Cattle Co. for providing the land, livestock, and facilities for this study; the Texas Experimental Ranch Committee for providing financial assistance; and David McKown, Texas A\&M University La Copita Research Area, for assistance in data collection.

Report is published with approval of the Director, Texas Agr. Exp. Sta. as TA 23221

Manuscript acoepted 24 August 1988.
}

uous grazing reduced patch grazing on Kansas rangelands. However, Gammon and Roberts (1978) and Kirby et al. (1986) compared continuous grazing (CG) to intensive multi-pasture 1 herd rotational grazing (RG) and found no significant differences in community preference between grazing systems, a result supported by the present study. Still, the presumed reduction in spatial variation in forage utilization is often a major factor justifying the implementation of multi-paddock, 1-herd rotational grazing systems (Kothmann 1980, Savory and Parsons 1980, Malechek and Dwyer 1983).

The objective of this research was to investigate cattle selectivity and preference for plant communities as affected by RG at 2 livestock densities. A yearlong CG treatment was included in the study as a control treatment. Plant communities were chosen as the spatial unit of interest because it is the hierarchical level at which tactical planning decisions are made and because previous work has indicated that this is the spatial unit of relevance to grazing cattle (Senft et al. 1985). We hypothesized that as stock density, grazing pressure, and intensity of rotation increased from the CG to the RG treatment that cattle would show less selectivity for the available plant communities.

\section{Materials and Methods}

\section{Study Area and Treatments}

The study was conducted at the Texas Experiment Ranch located $\left(99^{\circ} 14^{\prime} \mathrm{W}, 33^{\circ} 20^{\prime} \mathrm{N}\right)$ on the eastern edge of the Rolling Plains resource region. The climate is continental, semiarid, and highly variable. Annual precipitation is bimodally distributed and averages $682 \mathrm{~mm}$. Peak precipitation months are May $(96 \mathrm{~mm})$ and September $(118 \mathrm{~mm})$. Average maximum daily temperatures range from $11.4^{\circ} \mathrm{C}$ in January to $35.8^{\circ} \mathrm{C}$ in July. Average minimum daily temperatures range from $-2.4^{\circ} \mathrm{C}$ in January to $22.0^{\circ} \mathrm{C}$ in July.

The 465-ha, cell-designed (paddocks radiating from a common center) RG treatment was initiated in March 1981. Initially the treatment consisted of 14 paddocks that averaged 33 ha in size. The treatment was originally stocked with 125 Angus $X$ Hereford crossbed cows at a heavy rate of 3.7 ha $\bullet$ cow $^{-1} \cdot$ year $^{-1}$. Stocking rate was constant until June 1984 when it was reduced to 5.2 ha $\bullet$ cow $^{-1} \cdot$ year $^{-1}$ because of drought. In March 1982 a 30-ha paddock was divided twice creating three 10-ha paddocks for a total of 16 paddocks in the RG treatment. Cattle behavior and distribution data were collected on 5 paddocks including three 10-ha paddocks and two 27-ha paddocks located adjacent to the 10-ha paddocks (Fig. 1). Rate of rotation was flexible and varied according to vegetation growth rates and nutrient requirements of the cows. Days of rest between grazing periods ranged from about 30 to 65 . Stocking rate on the different size study paddocks was kept constant by varying the length of graze. Based on desired rest periods, length of graze in the 5 paddocks ranged from 18 hours to 2 days in the 10-ha paddocks and from 2 to 5 days in the 27-ha paddocks. These treatments were designed to simulate either a 14-or 42-paddock RG system. The 10-ha paddocks are referred to as the RG-42 treatment and the 27-ha paddocks as the RG-14 


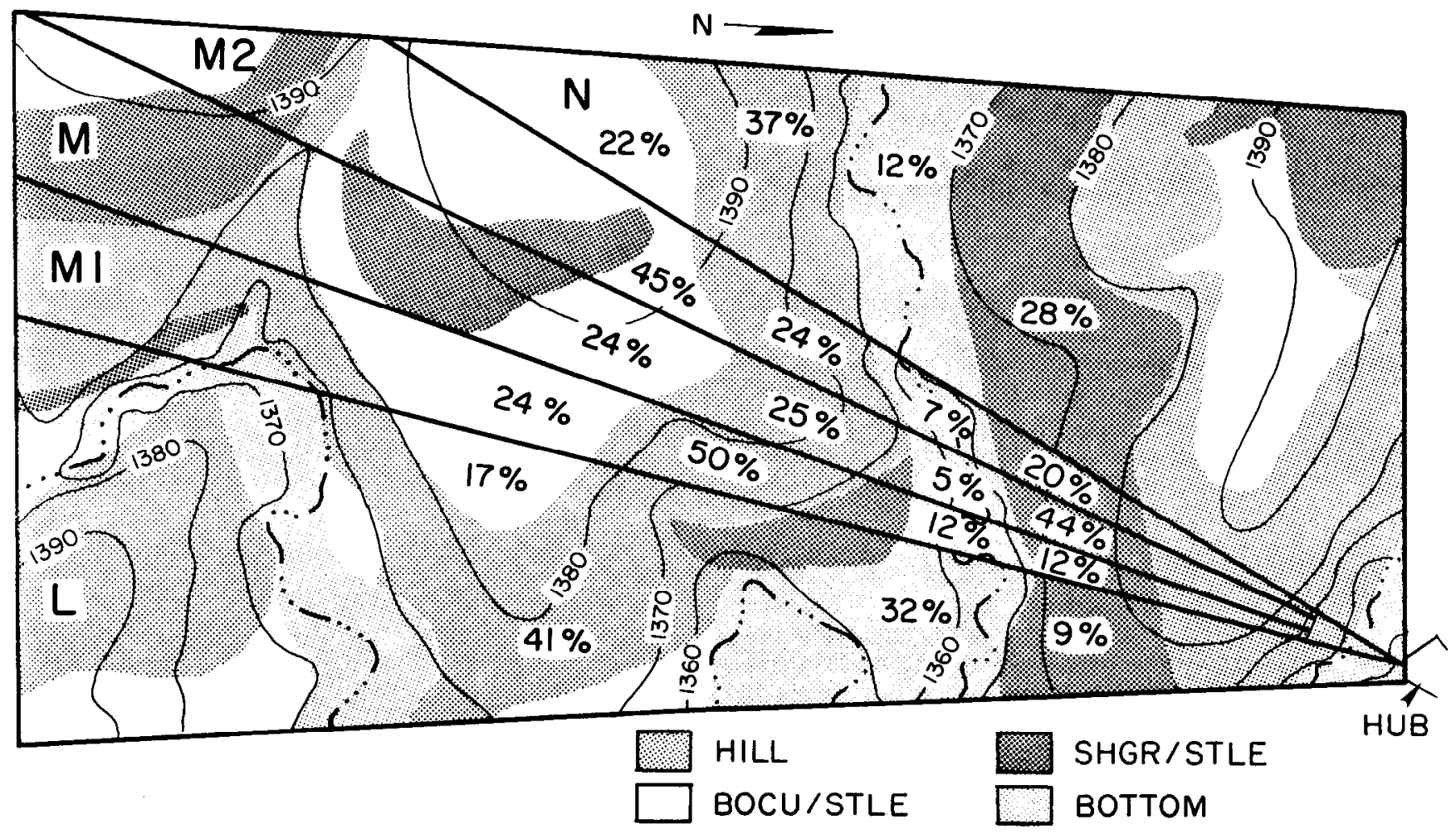

Fig. 1. Map of the rotationally grazed paddocks showing 3-m contour intervals and delineation of plant communities. Paddocks $L$ and $N$ were in the $R G-14$ treatment and Pastures $M 1, M$, and M2 were in the RG-42 treatment. Numbers within a plant community represent the percent of the paddock that was occupied by each plant community.

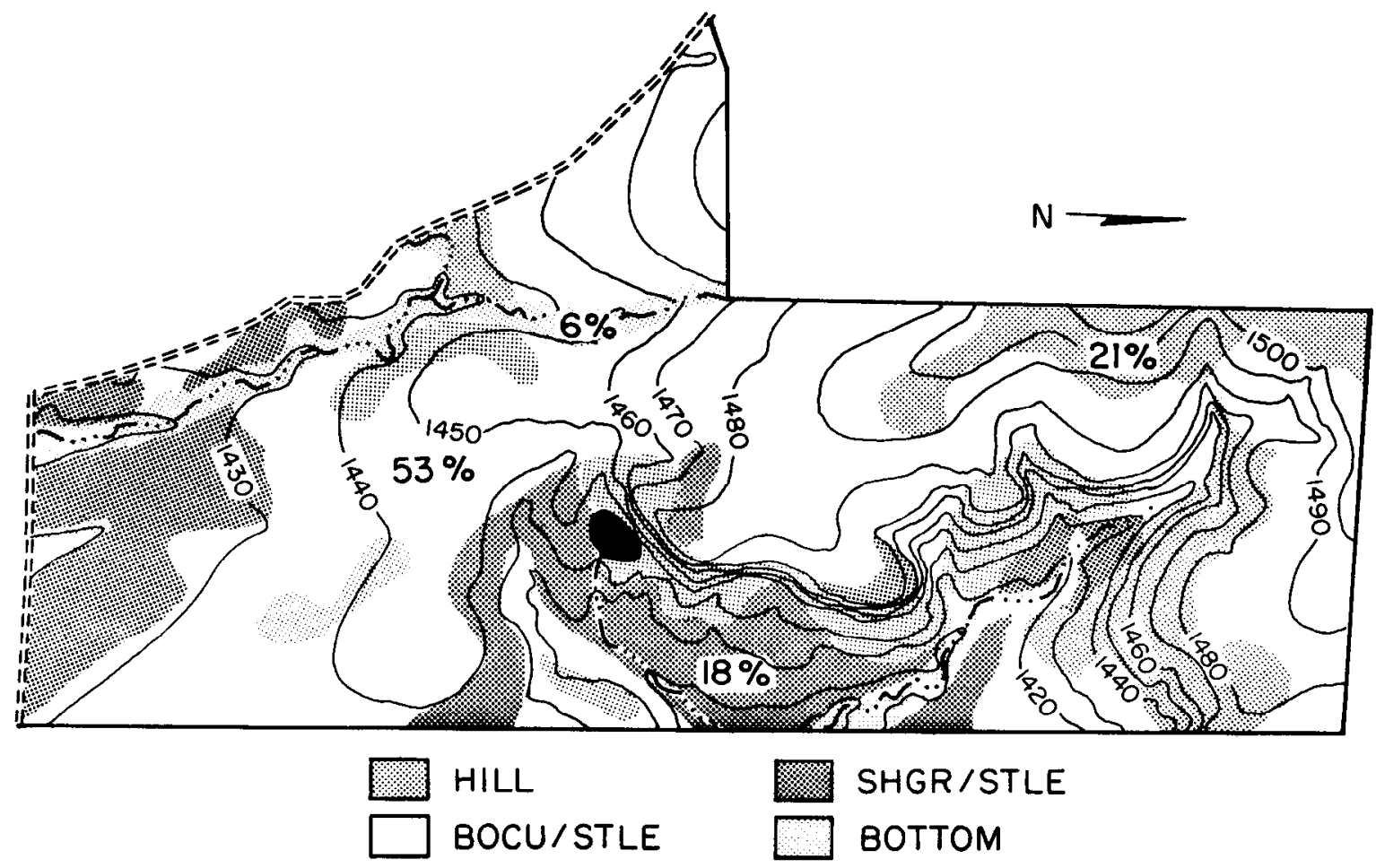

Fig. 2. Map of the continuously grazed pasture showing 3-m contour intervals and delineation of plant communities. Numbers within a plant community represent the percent of the pasture occupied by each plant community. 
treatment. The radial length of all $R G$ paddocks was about $1.3 \mathrm{~km}$.

The CG treatment was a single, 248-ha pasture that had been stocked at a moderate rate since 1960 and was stocked at 5.9 ha - cow $^{-1} \cdot$ year $^{-1}$ throughout this study. The longest dimension of this pasture is $2.7 \mathrm{~km}$ and the farthest distance to the centrally located water was $1.4 \mathrm{~km}$ (Fig. 2).

For the purposes of this paper 4 plant communities were identified based on differences in floristic composition, soil type, and topographic position. A general description of each is presented in Table 1. Sacrifice areas near permanent water were also delineated in all study areas. Range condition in all treatment pastures was good. For a more detailed description of the study area and study design, see Heitschmidt et al. (1985, 1987).

\section{Observations of Cattle Behavior}

Cattle were observed simultaneously in the CG and RG treatments during 8 seasonal trials conducted between October 1982 and August 1984. Trials were begun when cattle entered the first RG-14 paddock (i.e., pasture L). Trials lasted from 6 to 15 days and observations were made hourly using scan sampling (Altmann 1974) between daylight and dark for a total of 75 observation days in each treatment. The location, area occupied, activity, and number of cows in each herd or subherd was recorded on topographical maps. Activities were classified as grazing, loafing or mixed. Subherds were classified as grazing or loafing when $90 \%$ or more of the animals within the subherd were engaged in the specified activity. When less than $90 \%$ of the animals within a subherd were engaged in the same activity the subherd was classified as mixed. Night time observations were not attempted because of labor constraints and because night time activity is generally confined to the area where cattle bed for the night (Johnstone-Wallace and Kennedy 1944, Weaver and Tomanek 1951, Dwyer 1961, Senft et al. 1985).

\section{Data Analysis}

Number of animals observed in each plant community at each hourly observation was summed by trial, pasture, and activity, and divided by total number of animals in all communities to determine percent occupancy in each plant community. When the area occupied by a herd was located on more than 1 plant community, the animals in that herd were proportionally allocated to the different communities based on the area of the herd in each community. Data were summarized using selectivity (SI) and relative electivity (RE) indices. The selectivity index is a measure of the proportion of the time that the animals were not selecting communities in proportion to their availability (Van Dyne et al. 1980). This selectivity index has a value of 0 when plant communities are occupied in the same proportion as their availability and a value of 1 at maximum selectivity. Relative electivity estimates preference for individual communities and has a value of zero for random selection and a possible range between 1 (preferred) and -1 (avoided). Lechowicz (1982) stated that RE embodies a measure of the community's value as a function of both its abundance and the abundance of other communities available. He also suggested that RE can be used to make comparisons of preference from diverse environments, and that RE is a non-linear index and not amenable to parametric analysis. However, the data reported in this study were analyzed for departures from analysis of variance assumptions as suggested by Stroup et al. (1986) and within the range of data reported the residual errors were generally normally distributed. Furthermore, rank order transformation (Conover and Iman 1981) of RE had only minor effects on the results of the analysis.

The selectivity index was analyzed separately for each activity (i.e., grazing, loafing, and mixed) using repeated measurements least squares analysis of variance with grazing treatment (i.e., RG-42, RG-14, and CG) as the main plot and trial as a sub-plot. Relative electivity was analyzed in a similar manner except plant communities were sub-plots and trials were sub-sub-plots (Engeman et al. 1986). Data from the RG-14 treatment were further analyzed to determine if distribution (loafing activity was not analyzed because of missing data) differed between the initial and

Table 1. General descriptive parameters of the 4 plant communities delineated for study.

\begin{tabular}{|c|c|c|c|c|c|c|c|}
\hline Community & Code & Dominant Grasses' & ANPP $^{2}$ & $\begin{array}{l}\text { Topo- } \\
\text { sequence }\end{array}$ & Slope & $\begin{array}{c}\text { Soil } \\
\text { texture }\end{array}$ & $\begin{array}{l}\text { Shrub } \\
\text { canopy }\end{array}$ \\
\hline Hill & HILL & $\begin{array}{l}\text { Sideoats grama } \\
\text { (Bouteloua curtipendula) } \\
\text { Silver bluestem } \\
\text { (Bothriochola saccharoides) }\end{array}$ & 2500 & Ridge & $3-12 \%$ & $\begin{array}{l}\text { Rocky clays, } \\
\text { clay loams, \& } \\
\text { silty clay } \\
\text { loams }\end{array}$ & $<5 \%$ \\
\hline \multirow[t]{4}{*}{$\begin{array}{l}\text { Sidecats grama/ } \\
\text { Texas wintergrass }\end{array}$} & BOCU/STLE & Sideoats grama & 3000 & Mid-slope & $0-3 \%$ & Clay loams & $10-20 \%$ \\
\hline & & $\begin{array}{l}\text { Texas wintergrass } \\
\text { (Stipa leucotrica) }\end{array}$ & & & & & \\
\hline & & $\begin{array}{l}\text { Buffalograss } \\
\text { (Buchloe dactyloides) }\end{array}$ & & & & & \\
\hline & & $\begin{array}{l}\text { Japanese brome } \\
\text { (Bromus japonicus) }\end{array}$ & & & & & \\
\hline \multirow{4}{*}{$\begin{array}{l}\text { Shortgrass/ } \\
\text { Texas wintergrass }\end{array}$} & SHGR/STLE & Buffalograss & 2500 & Variable & $0-3 \%$ & Clay & $10-20 \%$ \\
\hline & & Texas winter grass & & & & & \\
\hline & & $\begin{array}{l}\text { Tumblegrass } \\
\text { (Schedonnardus paniculatus) }\end{array}$ & & & & & \\
\hline & & Japanese brome & & & & & \\
\hline \multirow[t]{4}{*}{ Bottom } & ВOTTOM & Texas wintergrass & 3300 & Drainage & $<1 \%$ & Clay & $5-10 \%$ \\
\hline & & Buffalograss & & & & & \\
\hline & & Japanese brome & & & & & \\
\hline & & Sideoats grama & & & & & \\
\hline
\end{tabular}

'Dominance based on frequency data from 200 quadrats/community/replication (unpublished). Dominant species had average frequency $>40 \%$ in $0.25 * 0.50 \mathrm{~m}$ frames. ${ }^{2}$ Average above ground net primary production from Heitschmidt et al. (1985).

${ }^{3}$ From Heitschmidt et al. (1985) 
final day in a paddock using a within paddock split-plot and split-split-plot analysis for SI and RE, respectively. If the covariance matrix of the repeated measures analysis did not satisfy the Huynh-Feldt condition, the probability level of the associated F-ratio was based on the Box correction for degrees of freedom (Huynh and Feldt 1976). Protected least significant differences were used for mean separation. These analyses used the variation among the 2 paddocks in the RG- 14 treatment and the 3 paddocks in the RG-42 treatment to estimate experimental error caused by grazing treatment in this grazing treatment case study.

\section{Results}

The selectivity index for grazing cattle differed among all grazing treatments $(P<0.001)$, but was not affected by trial or the grazing treatment by trial interaction (Fig. 3). Mean SI was 0.15,
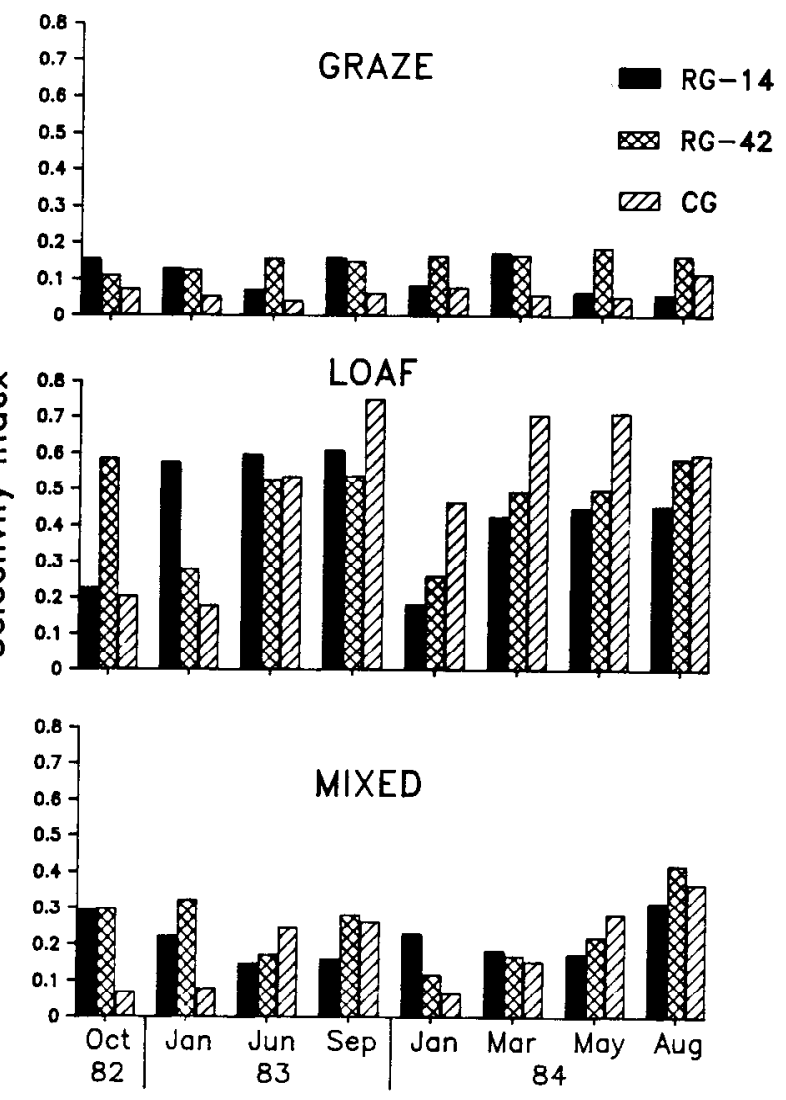

Fig. 3. The effect of grazing treatment on selectivity index in grazing, loafing or mixed activities in 4 plant communities on 8 dates.

0.10 , and 0.07 for the RG-42, RG-14, and CG treatments, respectively. These results refute our initial hypothesis and the common belief that increasing stock density with rotational grazing will reduce selective grazing of plant communities. There were no significant grazing treatment interactions for the RE of grazing cattle. This indicates that grazing treatments did not affect relative preference or avoidance for communities (Fig. 4). Thus the increase in SI was a result of differences in the degree of selective occupancy of plant communities and not due to major changes in cattle preference for plant communities.

Selectivity of loafing cattle was affected by trial $(P<0.01)$ and the trial $\times$ treatment interaction $(P<0.07)$, but was similar among grazing treatments. Averaged across grazing treatments, cattle were less selective for loafing sites during the October 1982 and January 1983 and 1984 trials compared to the other trials (Fig. 3). The

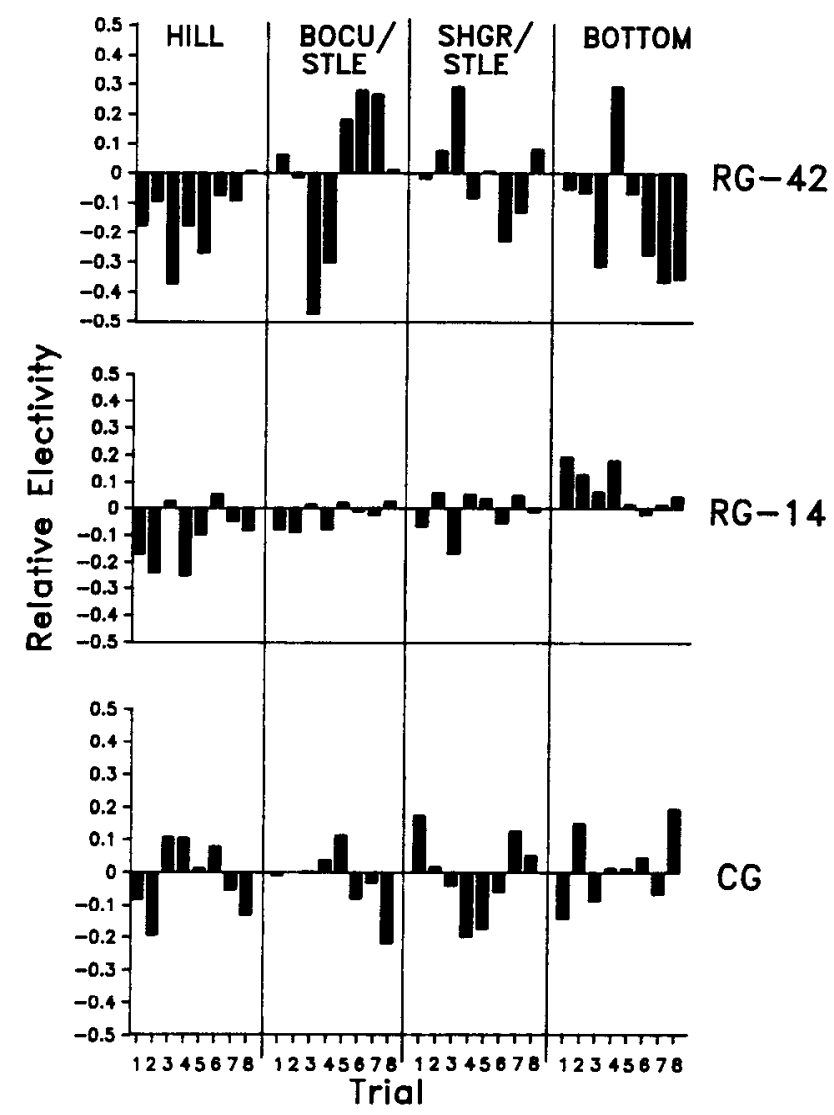

Fig. 4. The effect of grazing treatment on relative electivity based on percentage of grazing cattle observed in 4 plant communities on 8 trials. Trial dates were: $1=\operatorname{Oct} 82,2=J a n ~ 83,3=J u n ~ 83,4=\operatorname{Sep} 83,5=J a n 84$, $6=\operatorname{Mar} 84,7=\operatorname{May} 84,8=\operatorname{Aug} 87$.

grazing treatment $X$ trial interaction was caused by an inconsistency of this seasonal trend of SI among grazing treatments during different trials. Relative electivity of loafing cattle for plant communities was affected by type of community $(P<0.006)$. In general areas around water were preferred loafing sites, and the HILL and BOCU/STLE communities were avoided (Fig. 5). This pattern was modified by grazing treatment and trial. The three-way interaction was caused primarily by a consistent preference for the area around permanent water in the CG treatment compared to a less consistent preference for this site in the rotationally grazed treatments. The cattle in the RG-42 treatment demonstrated greater preference for the BOTTOM communities and greater avoidance of the area near water than the other 2 grazing treatments. However, this pattern was most likely an artifact of pasture configuration and land area classification than a representation of cattle preference. In all $R G$ paddocks the hub area of the grazing cell was the only location classified as water (Fig. 1). Cattle in the RG treatments often loafed in the BOTTOM community adjacent to the hub, and this trend was particularly prevalent in the RG-42 treatment where this area was common to all 3 paddocks in that treatment. Thus, preference for water as a loafing site was somewhat confounded with the BOTTOM community in the RG treatments, and was probably the reason the treatment $X$ community $X$ trial interaction was significant.

Analysis of SI and RE of cattle herds engaged in mixed activities showed that the only significant effect was for type of plant community on RE $(P<0.01)$. This effect indicated that cattle engaged in a mixture of activities preferred the BOTTOM communities and avoided the HILL and BOCU/STLE communities (Fig. 6). The similarity in preference for plant communities exhibited by cattle 


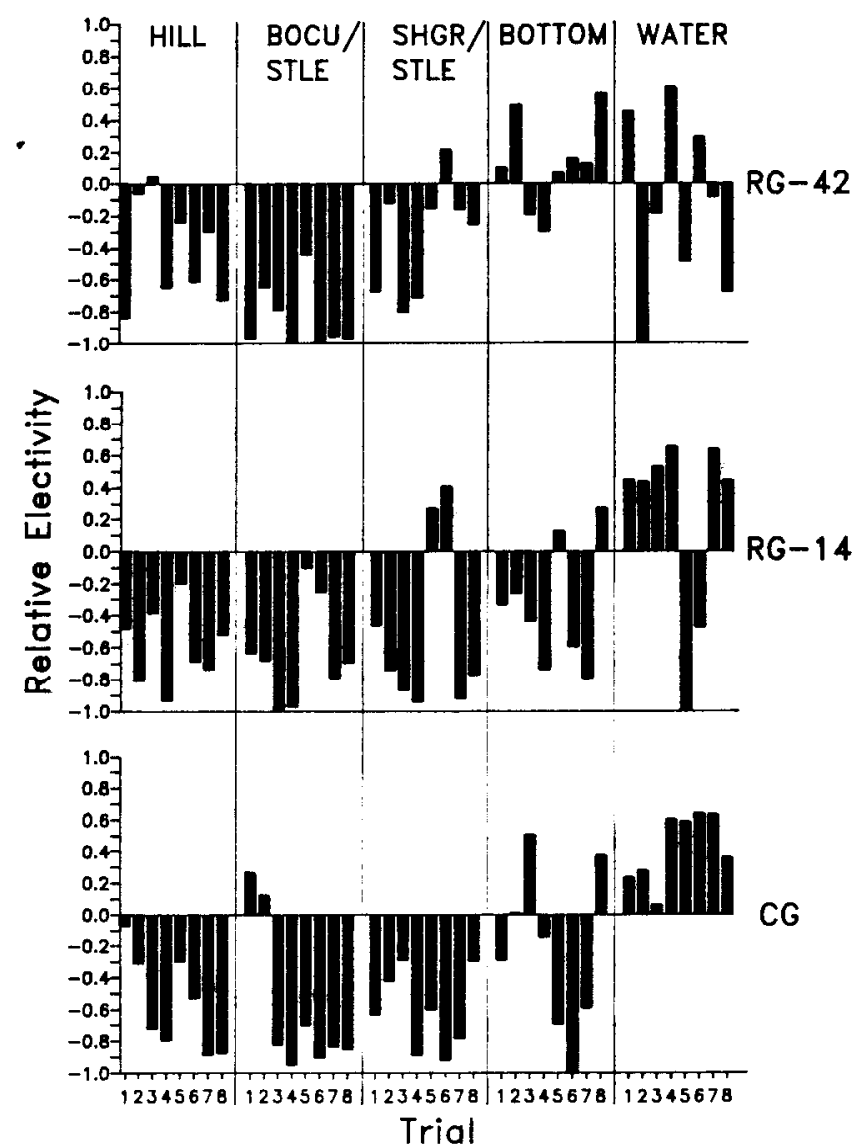

Fig. 5. The effect of grazing treatment on relative electivity based on percentage of loafing cattle observed in 4 plant communities on 8 trials. Trial dates are described in Figure 4.

engaged in loafing and mixed activities indicated that herds classified as mixed were often in a transition between loafing and grazing.

The degree of selectivity was affected by activity. Grazing cattle were less selective than animals engaged in other activities. The SI averaged $0.10,0.22$, and 0.48 for grazing, mixed, and loafing herds, respectively. This relationship resulted from a decrease in area occupied by herds as their activity changed from grazing to loafing.

There were only minor differences in cattle distribution between the first and last day in the RG-14 paddocks. The SI for plant communities of grazing cattle did not change between the first and last day in a paddock. Although the day $\times$ community $X$ trial interaction for RE of grazing cattle was significant $(P<0.05)$, subsequent analysis of the ranked data was not significant $(P>0.20)$. The SI decreased $(P<0.07)$ from 0.29 on the first day to 0.19 on the last day in a paddock for herds engaged in mixed activities. Preference for plant communities by mixed activity herds was affected by the community $\times$ trial $(P<0.04)$ and day $\times$ community $X$ trial $(P<0.01)$ interactions. The mixed RE 3-way interaction indicated that generally the HILL community was less preferred, and the BOTTOM community more preferred on the first day in a paddock compared to the last day, but this trend was not consistent across trials.

\section{Discussion}

The results of this study indicate that selection for plant communities by cattle was either not affected or that selectivity (i.e., nonuniform grazing) was slightly increased by rotational grazing systems that created very high stock densities compared to contin-

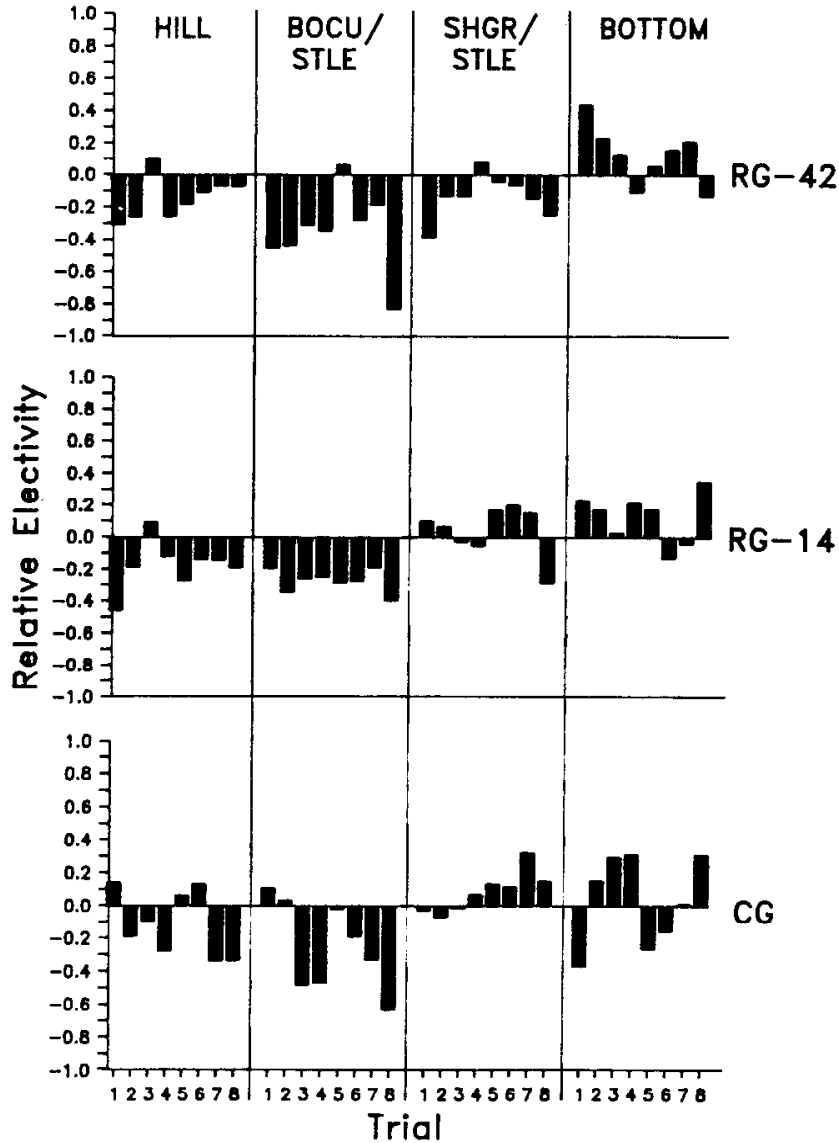

Fig. 6. The effect of grazing treatment on relative electivity based on percentage of cattle observed in 4 plant communities on 8 trials during periods of mixed activity. Trial dates are described in Figure 4.

uous grazing. Stock densities ranged from 0.17 cows $\bullet \mathrm{ha}^{-1}$ in the CG pasture to 12.50 cows $\bullet \mathrm{ha}^{-1}$ in the RG-42 paddocks; a 74-fold difference. These results indicate that our original hypothesis was false. However, if RE and SI were calculated on a daily basis instead of based on the average use during a trial the results would have been altered. On a daily basis cattle in the CG treatment were more selective for plant communities. This occurred because the communities were not evenly distributed in the CG pasture (Fig. 2) and the animals generally remained either north or south of the centrally located water source during a single day. This behavior was the result of physical limits on the ability of cattle to cover all of this 248-ha pasture in a day. However, by using different ends of the pasture on different days throughout a trial, cattle distribution relative to plant communities was as uniform in the CG as in the RG treatments.

The importance of this study is the relationship of these results to other grazing behavior studies and to the general principles of grazing management. When single-herd multi-pasture rotational grazing has been compared to continuous grazing on a yearlong or seasonlong basis, rotational grazing has not resulted in more uniform utilization of forage at either the individual plant or community level (Gammon and Roberts 1978, Kirby et al. 1986). However, intensive early stocking has resulted in more uniform utilization than continuous grazing (Smith and Owensby 1978, Ring et al. 1985). The major difference between the rotational grazing studies (including ours) and intensive early stocking is that the former require management tactics that insure a forage reserve is accumulated during periods of active growth for consumption during periods of slow growth. This is not a consideration with IES 
because it is designed to utilize a major portion of the forage available in a paddock during each grazing event. Grazing distribution appears to be more sensitive to the amount of standing herbage than to grazing pressure or stock density. This hypothesis is supported by this study in conjunction with our previous data (Heitschmidt et al. 1987). The previous data collected on the same pastures used in this study indicated more total standing crop but similar amounts of live standing crop in the CG compared to the RG treatments. Thus, in the present study, plant community preference and forage standing crop were rather similar between RG and CG treatments whereas there was about a 74-fold difference among the treatments in livestock density, which would have resulted in similar differences in grazing pressure.

Other grazing behaviors such as grazing time, bite size, and bite rate have been shown to be more sensitive to the amount of forage available on a unit area of land basis than on an animal demand or stock density basis (Chacon and Stobbs 1976, Chacon et al. 1976, Jamieson and Hodgson 1979, Hendricksen and Minson 1980). We hypothesize that most grazing behaviors will be affected more by forage standing crop on an area basis than on an animal demand basis. This hypothesis implies that if pastures are grazed yearlong or seasonlong, grazing systems will have little effect on livestock distribution within the occupied pastures. This is primarily a result of the necessity of leaving sufficient forage at the end of one grazing period to insure that during subsequent grazing periods there will be adequate forage to meet the nutrient demands of the livestock. Reserving current forage production for future demand tends to ensure that forage standing crop dynamics will be rather similar among different grazing systems when they are grazed yearlong or seasonlong. This hypothesis contradicts the hypothesis that short duration grazing will improve grazing distribution of livestock and promote more uniform utilization of forage (Kothmann 1980, Savory and Parsons 1980, Malechek and Dwyer 1983). Our hypotheses are not new and tend to support Voisin's $(1959$, p. 100) contention that "there is one way to baffle the cow's instinct: starve her". He recommended rotational grazing only on growing pastures, and the use of conserved forages during dormancy.

If the objective of grazing management is to manipulate the environment at the plant-animal interface to increase the efficiency of forage harvest, then controlling the amount of available forage may be the most effective tool. However, this severely limits the alternatives available to producers who maintain livestock on rangelands yearlong. These results also indicate that the grazing management strategy of forcing livestock to graze rangelands uniformly by using high grazing pressure may be ineffective. It was apparent from this study that certain characteristics of the environment such as watering points and shade trees were important determinants of favored loafing sites regardless of grazing system. Because loafing sites influence the distribution of herds engaged in mixed activity (38\% of the observations), and to a lesser extent grazing herds, a more complete understanding of environmental cues that attract livestock to loafing sites would be of practical importance. Such knowled ge could help managers design pastures that would induce livestock to harvest forage more efficiently.

\section{Literature Cited}

Altmann, J. 1974. Observational study of behaviors: Sampling methods. Behaviour. 49:227-267.

Chacon, E.A. and T.H. Stobbs. 1976. Influence of progressive defoliation of a grass sward on the eating behavior of cattle. Australian J. Agr. Res. 27:709-727.

Chacon, E.A., T.H. Stobbs, and M.B. Dale. 1976. Influence of sward characteristics on grazing behavior and growth of Hereford steers grazing tropical grass pastures. Australian J. Agr. Res. 29:89-102.

Conover, W.J. and R.L. Iman. 1981. Rank transformation as a bridge between parametric and nonparametric statistics. The Amer. Stat. 35:124-129.
Dwyer, D.D. 1961. Activities and grazing preferences of cows with calves in northern Osage County, Oklahoma. Oklahoma Agr. Exp. Sta. Bull. B-588.

Engeman, R.M., D.E. Palmquist, and L.L. McDonald. 1986. The use of repeated measurement designs in field studies. p. 59-66. In: Statistical Analyses and Modeling of Grazing Systems Symposium Proc. 11 February 1986, Kissimmee, Florida. Soc. Range Manage. Denver, Colo.

Gammon, D.M., and B.R. Roberts. 1978. Patterns of defoliation during continuous and rotational grazing of the Matopos Sandveld of Rodesia 1. Selectivity of grazing. Rhod. J. Agr. Res. 16:117-131.

Heitschmidt, R.L., S.L. Dowhower, R.A. Gordon, and D.L. Price. 1985. Response of vegetation to livestock grazing at the Texas Experiment Ranch. Texas Agr. Exp. Sta. Bull. 1515.

Heitschmidt, R.L., S.L. Dowhower, and J.W. Walker. 1987. Some effects of a rotational grazing treatment on quantity and quality of available forage and amount of ground litter. J. Range Manage. 40:318-321.

Hendricksen, R., and D.J. Minson. 1980. The feed intake and grazing behavior of cattle grazing a crop of Lablab purpureus cv. Rongai. J. Agr. Sci. Camb. 95:547-554.

Huynh, H., and L.S. Feldt. 1976. Estimation of the Box correction for degrees of freedom from sample data in the randomized block and split plot designs. J. Educ. Stat. 1:69-82.

Jamieson, W.S., and J. Hodgson. 1979. The effect of variation in sward characteristics upon ingestive behavior and herbage intake of calves and lambs under a continuous stocking management. Grass and Forage Sci. 34:190-197.

Johnstone-Wallace, D.B., and K. Kennedy. 1944. Grazing management practices and their relationship to the behavior and grazing habits of cattle. J. Agr. Sci. 34:190-197.

Kirby, D.R., M.F. Pessin, and G.K. Clambey. 1986. Disappearance of forage under short-duration and season-long grazing. J. Range Manage. 39:496-500.

Kothmann, M.M. 1980. Evaluation of livestock needs on designing grazing systems for rangeland. Chap. 6 Part B. In: Digestive Physiology and Nutrition of Ruminants, D.C. Church (ed.), Vol. 3 O\&B Books, Inc. Corvallis, Ore.

Low, W.A., M.L. Dudzinski, and W.J. Muller. 1981. The influence of forage and climatic conditions on range community preference of shorthorn cattle in central Australia. J. Appl. Ecol. 18:11-26.

Lechowicz, M.J. 1982. The sampling characteristics of electivity indices. Oecologia 52:22-30.

Malechek, J.C., and D.D. Dwyer. 1983. Short-duration grazing doubles your livestock? Utah Sci. 44:32-37.

Roath, L.R., and W.C. Krueger. 1982. Cattle grazing behavior on a forest range. J. Range Manage. 35:332-333.

Savory, A., and S. Parsons. 1980. The Savory grazing method. p. 215-221. In: Beef Cattle Science Handbook, M.E. Ensiminger (ed.), Vol 17.

Senft, R.L., M.B. Coughenour, D.W. Balley, L.R. Rittenhouse, O.E. Sala, and D.M. Swift. 1987. Large herbivore foraging and ecological hierarchies. Bioscience 37:789-799.

Senft, R.L., L.R. Rittenhouse, and R.G. Woodmansee. 1985. Factors influencing patterns of cattle grazing behavior on shortgrass steppe. J. Range Manage. 38:82-87.

Smith, E.F., and C.E. Owensby. 1978. Intensive-early stocking and seasonlong stocking of Kansas flint hills range. J. Range Manage. 31:14-17.

Stroup, W.W., S.S. Waller, and R.N. Gates. 1986. Exposition on the selection of appropriate experimental design and statistical analysis for pasture improvement research. J. Range Manage. 39:200-207.

Ring, C.B., II, R.A. Nicholson, and J.L. Launchbaugh. 1985. Vegetational traits of patch-grazed rangeland in west-central Kansas. J. Range Manage. 38:51-55.

Tanner, G.W., L.D. Sandoval, and F.G. Martin. 1984. Cattle behavior on a south Florida range. J. Range Manage. 37:248-251.

Van Dyne, G.M., N.R. Brockington, A. Sozoss, J. Duek, and C.A. Ribic. 1980. Large herbivore subsystems. p. 269-535. In: A.I. Breymeyer and G.M. Van Dyne (eds.), Grassland, Systems Analysis and Man. Int. Biol. Programme 19. Cambridge University Press.

Voisin, Andre. 1959. Grass productivity. Philosophical Library, Inc. New York, NY.

Wamon, K.A. 1968. Use of different classes of rangeland by cattle. California Agr. Exp. Bull. 838.

Weaver, J.E., and G.W. Tomanek. 1951. Ecological studies in a Midwestern range. The vegetation and effects of cattle on its composition and distribution. Nebraska Conserv. Bull. 31. 